\title{
Postnatal Mice Have Low Susceptibility to Paracetamol Toxicity
}

\author{
GREGORY M. ADAMSON, JOHN M. PAPADIMITRIOU, AND ANDREW W. HARMAN
}

Departments of Pharmacology [G.M.A., A.W.H.] and Pathology [J.M.P.], The University of Western Australia, Nedlands, Western Australia 6009, Australia

\begin{abstract}
The hepatotoxicity of paracetamol in mice of $2,3,8-10,24-26,32-34$, and 52-54 wk of age was determined by lethality data, histopathologic examination of the liver, and appearance of glutamate-pyruvate transaminase and glutamate-oxaloacetate transaminase activities in the plasma over an 8-h exposure period. At a dose of $300 \mathrm{mg} / \mathrm{kg}$, there was evidence of hepatocytic necrosis and transaminase leakage in the 32- to 34- and 52- to 54wk-old mice, but lethality was only recorded in the oldest age group. At $500 \mathrm{mg} / \mathrm{kg}$, paracetamol produced $30 \%$ lethality in 3-wk-old mice and between 50 and $90 \%$ lethality in the adult age groups. There was histologic evidence of hepatocytic necrosis at all of these ages and its extent increased with age. Similarly, there were increases in plasma transaminases in each of these age groups. However, in 2-wk-old mice there was no lethality, no hepatocytic necrosis, and no increase in plasma transaminases. The lack of susceptibility of 2-wk-old mice to paracetamol toxicity was not due to immaturity of the cytochrome $P$ 450 enzymes responsible for metabolism of paracetamol to its reactive metabolite ( $\mathbf{N}$-acetyl-p-benzoquinone imine). In fact, the activity of this enzyme pathway in 2-wk-old mice was greater than that in adults. The partial clearance of the glutathione-derived metabolites of paracetamol after a nontoxic $(50 \mathrm{mg} / \mathrm{kg})$ dose was $80 \%$ greater in 2-wk-old mice than in 8- to 10 -wk-old mice. Therefore, despite having greater capacity to generate $\mathrm{N}$-acetyl-p-benzoquinone imine, 2-wk-old mice had no hepatotoxic effects from a dose that killed at least $50 \%$ of adult mice. Factors that relate to the detoxification of $\mathrm{N}$-acetyl-p-benzoquinone imine in the liver are implicated in the lesser susceptibility of postnatal mice to paracetamol toxicity. (Pediatr Res 29: 496-499, 1991)
\end{abstract}

\section{Abbreviations}

GOT, glutamate-oxaloacetate transaminase

GPT, glutamate-pyruvate transaminase

GSH, reduced glutathione

NAPQI, $\mathbf{N}$-acetyl-p-benzoquinone imine

High doses of paracetamol cause liver injury in a variety of animal species and in man as a result of its activation to a highly reactive metabolite (1). The susceptibility of hepatocytes to paracetamol is a complex interplay between paracetamol's rate of activation to the putative toxic metabolite, NAPQI (1), the ability

Received August 7, 1990, accepted November 26, 1990

Correspondence and reprint requests: Dr. Andrew W. Harman, Department of Pharmacology, The University of Western Australia, Nedlands, W.A. 6009, Australia.

Supported by grants from The National Health and Medical Research Counci of Australia and the TVW Telethon Foundation of Western Australia. to detoxify this metabolite by conjugation to GSH (2-4), and a number of incompletely understood processes initiated by NAPQI that lead to cell death (5).

It is generally accepted that children are less susceptible to paracetamol toxicity than are adults (6). This impression has developed from clinical observations that the incidence of overdose toxicity is less in the young (7). However, the scientific basis for this has yet to be confirmed.

Our present study is aimed at examining developmental aspects of the susceptibility of mice to paracetamol toxicity. Previous work in this field has been conflicting, with some research indicating that young mice (8) and rats (9) are more susceptible to high doses of paracetamol. However, the majority of findings indicate that during the postnatal period young rats and mice are less susceptible to toxicity $(10,11)$. These latter observations have been attributed to the immaturity of the cytochrome P450-linked mixed function oxidase enzymes in the postnatal period and the consequent decrease in the rate of activation of paracetamol to NAPQI (10) or to a lack of susceptibility to hepatotoxins in general (12). We have recently observed that hepatocytes from postnatal mice are less susceptible to the toxic effects of paracetamol when compared with cells from adults (13). However, this lack of susceptibility in the cells from postnatal mice was not due to the immaturity of the enzymes that activate paracetamol to NAPQI (14).

Our study examined the toxicity of paracetamol in groups of mice ranging in age from $2 \mathrm{wk}$ to $1 \mathrm{y}$. It aimed to determine if there is an age-related difference in susceptibility to high doses of paracetamol and whether differences are related to the rate of paracetamol metabolism.

\section{MATERIALS AND METHODS}

Animals. Male and pregnant female Swiss ARC mice (derived from Charles River CD-1 mice; Charles River Laboratories, Wilmington, MA) were obtained from the Animal Resources Center (Murdoch, Western Australia). Male adult animals were housed in community cages in groups no larger than 10 . Pregnant females were caged separately. After birth, litters were kept with their dams until weaned. The day of birth was recorded as the first morning of observation. All animals had free access to food (RM II autoclavable rat and mouse cubes; Glenn Forrest Stockfeeders, Perth, Western Australia) and tap water. Male mice were separated from females in each litter at 3 wk of age. All animals were maintained at $24^{\circ} \mathrm{C}$ in a constant environment with a 12 -h light/dark cycle (0600 to $1800 \mathrm{~h})$.

Acute hepatotoxicity in vivo. Groups of mice $(2,3,8-10,26-$ $28,32-34$, or 52-54 wk of age) received paracetamol as either a $300-$ or $500-\mathrm{mg} / \mathrm{kg}$ dose (intraperitoneally) in saline between 0800 and $0900 \mathrm{~h}$ in a volume of $20 \mathrm{~mL} / \mathrm{kg}$. These doses were chosen on the basis of previous experience to be a threshold toxic dose and an $\mathrm{LD}_{50}$ dose, respectively, in young adults. Control animals were injected with an equal volume of saline. During the following $8 \mathrm{~h}$, any animal that was considered from our 
experience to be near death (moribund and shallow respiration) was killed by cervical dislocation. This was in accordance with the Institution's Animal Ethics guidelines for this type of experiment. These incidences only occurred after $6 \mathrm{~h}$. A blood sample was taken by syringe from the heart and transferred to heparinized microcentrifuge tube for separation of plasma by centrifugation at $2000 \mathrm{rpm}$ for $5 \mathrm{~min}$. Plasma was then analyzed for activity of GOT (EC 2.6.1.1) and GPT (EC 2.6.1.2), using the method of Bergmeyer and Bernt $(15,16)$ adapted for a Roche Centrifugal Analyser (Hoffman-LaRoche, Basel, Switzerland). Mid-lateral sections of the caudate lobe of the liver were also removed and placed in $10 \%$ buffered formal saline. After $8 \mathrm{~h}$, surviving mice were killed and blood and tissue samples taken as described above. Liver tissue was fixed for $24 \mathrm{~h}$ in $10 \%$ formal saline, then embedded in paraffin wax. Sections $(5 \mu \mathrm{m})$ were cut from paraffin blocks cooled to $4^{\circ} \mathrm{C}$, then mounted on glass slides. Sections were stained with hematoxylin and eosin for histopathologic examination (17). Hepatic sections were examined under the light microscope for extent of necrosis and other morphologic changes. These examinations were carried out in a single blind manner by one of us (J.M.P.).

Pharmacokinetic studies. Radiolabeled $\left[{ }^{14} \mathrm{C}\right.$-phenyl]-paracetamol was obtained from Amersham International (Little Chalfont, $\mathrm{UK}$ ) and had a sp act of $19.5 \mathrm{mCi} / \mathrm{mmol}$. Purity of the radiolabel was determined by thin layer chromatography on silica gel $\mathrm{G} /$ $\mathrm{UV}_{254}$ plates (Macherey Nagel Co., Duren, Germany) using both ethyl acetate, methanol, water, acetic acid (12:6:1.8:0.2) and $n$ butanol, water, aqueous ammonia $(20: 2: 1)$ as solvents. Paracetamol chromatographed to a single spot using both solvent systems. For the drug metabolism studies, approximately 200 $\mu \mathrm{Ci}$ of ${ }^{14} \mathrm{C}$-paracetamol was dissolved in absolute ethanol (10 $\mathrm{mL}$ ) along with $400 \mathrm{mg}$ unlabeled paracetamol (Sigma Chemical Co., St. Louis, MO). The ethanol was then evaporated under a stream of dry nitrogen, after which the labeled mixture was redissolved in isotonic saline to give a final concentration of 25 $\mathrm{mg} / \mathrm{mL}$. For plasma clearance determination, $50 \mu \mathrm{Ci}$ of ${ }^{14} \mathrm{C}$ paracetamol was mixed with unlabeled paracetamol and prepared as for the metabolism studies.

To determine plasma clearance, adult (8- to 10 -wk-old) and postnatal (2-wk-old) mice were administered ${ }^{14} \mathrm{C}$-paracetamol $(50 \mathrm{mg} / \mathrm{kg}$, intraperitoneally) between 0800 and $0850 \mathrm{~h}$. Paracetamol dose was based on body weight because the liver to body weight ratio was similar in both age groups (data not shown). Groups of four mice per age group were killed at 15, 30, 45, 60, 120,180 , and 240 min after dose administration and a blood sample taken from the heart into a heparinized tube. Unchanged paracetamol was extracted into ethyl acetate as described previously (18) and measured for radioactivity by liquid scintillation counting using a Packard 1500 Tri-Carb liquid scintillant analyzer (Packard Instrument Co., Downers Grove, IL) and internal standardization.

Drug metabolism studies were also carried out on 2- and 8- to 10 -wk-old mice using the same dosing regime. Urine was collected over a subsequent 8 -h period in metabolism cages, which were then rinsed with $50 \mathrm{~mL}$ methanol to recover any remaining urine. The urine remaining in the bladder was obtained by syringe after light pentobarbital anesthesia. The urine was assayed for the presence of paracetamol metabolites by HPLC (19). Analysis of metabolite peak areas was done using data acquisition and analysis software (DAPA Scientific Software, Kalamunda, Western Australia). Metabolite peaks were identified by comparison of retention times with those for authentic standards of paracetamol and its glucuronide, sulphate, mercapturate, cysteine, and glutathione conjugates. Paracetamol pharmacokinetics were determined using a one-compartment open model. Fractional clearance of the various paracetamol metabolites and unchanged paracetamol were determined by multiplying total clearance by the fraction of the dose recovered as each metabolite appearing in the urine.

Statistical analysis. Analysis of variance was performed using the statistical application GENSTAT (Laws Agricultural Trust, Rothamsted Experimental Station, Harpenden, UK). If a significant variance ratio was indicated, individual group differences were compared with controls by Dunnett's test (20). Two sample comparisons were by unpaired $t$ test (two-tailed).

\section{RESULTS}

Table 1 shows the lethality data from groups of mice receiving either 300 or $500 \mathrm{mg} / \mathrm{kg}$ paracetamol. At the $300-\mathrm{mg} / \mathrm{kg}$ dose, all postnatal (2- and 3-wk-old) mice survived for $8 \mathrm{~h}$, as did adult mice in the age range 2 to $9 \mathrm{mo}$. However, there was $30 \%$ lethality in 12 -mo-old mice. At $500 \mathrm{mg} / \mathrm{kg}$, there were no deaths in 2-wk-old mice. In 3-wk-old animals, there was $30 \%$ mortality. In the adult age groups, the lethality was between 50 and $90 \%$.

Centrilobular hepatic necrosis was a feature found in mice 3 wk to 12 mo of age that received the high dose of paracetamol $(500 \mathrm{mg} / \mathrm{kg})$, but the number of mice with evidence of necrosis varied with age. The severity of the necrosis in each group increased with age. It was least obvious in young mice ( $3 \mathrm{wk}$ of age) and most pronounced in old animals (6-12 mo old). No necrosis was present in postnatal 2-wk-old mice. In the oldest animals $(12 \mathrm{mo}$ old $)$, even the low dose $(300 \mathrm{mg} / \mathrm{kg})$ induced some hepatocytic necrosis. However, in postnatal 2- and 3-wkold animals there was no evidence of necrosis at this dose. All cases of necrosis resulted in focal hemorrhages in the affected areas.

The other morphologic changes (other than necrosis) common to all age groups after paracetamol administration at both doses were centrilobular hepatocytic atrophy, mild hepatocytic vacuolation, mild hepatocytic fatty change, loss of sinusoidal cells, focal peliosis, and sinusoidal congestion. These alterations were more pronounced in mice receiving the higher dose of paracetamol. Changes were most apparent in the central zone of hepatic lobules, all of which were uniformly affected. In mice injected with $500 \mathrm{mg} / \mathrm{kg}, 60$ to $70 \%$ of each lobule was morphologically deranged, whereas only 20 to $50 \%$ was affected by the lower dose of $300 \mathrm{mg} / \mathrm{kg}$, regardless of age.

Plasma GOT and GPT activities were used as biochemical indicators of hepatic damage. Enzyme activity in plasma taken from mice surviving the $8 \mathrm{~h}$ after dose administration was combined with data from animals killed during this period (Table 2). The lower dose of $300 \mathrm{mg} / \mathrm{kg}$ paracetamol did not increase either GOT or GPT activities in plasma from postnatal (2- and 3 -wk-old) mice or young adult (8- to 10 -wk-old) mice. In older adults (6-12 mo old), there were increases in the plasma level of GPT activity. In 2-wk-old mice, there was no increase in GOT or GPT activity after injection of $500 \mathrm{mg} / \mathrm{kg}$ paracetamol. However, this dose in the other age groups produced marked elevation of plasma GOT and GPT enzyme levels.

The total body clearance of paracetamol was estimated from the decline in plasma concentration with time (Fig. 1). The clearance rate in 2 -wk-old mice of $991 \pm 10 \mathrm{~mL} / \mathrm{h} / \mathrm{kg}$ (mean \pm SD) was slightly less than the value of $1093 \pm 37 \mathrm{~mL} / \mathrm{h} / \mathrm{kg}$ in

Table 1. The lethality of paracetamol in mice of different ages*

\begin{tabular}{cccc}
\hline & \multicolumn{3}{c}{ Lethality ${ }^{2}$} \\
\cline { 2 - 4 } Age (wk) & Control & $300 \mathrm{mg} / \mathrm{kg}$ & $500 \mathrm{mg} / \mathrm{kg}$ \\
\hline 2 & 0 & 0 & 0 \\
3 & 0 & 0 & 3 \\
$8-10$ & 0 & 0 & 7 \\
$24-26$ & 0 & 0 & 8 \\
$32-34$ & 0 & 0 & 5 \\
$52-54$ & 0 & 3 & 9 \\
\hline
\end{tabular}

* In each age group, 10 animals received either dose of paracetamol and four control animals received saline intraperitoneally.

$\dagger$ Number of deaths in $8 \mathrm{~h}$. 
Table 2. The effect of age on paracetamol-induced leakage of GOT and GPT enzyme activities (IU/L) in plasma (mean \pm $\operatorname{SEM}, n=10$ for paracetamol-treated, $n=4$ for controls)

\begin{tabular}{|c|c|c|c|c|c|c|}
\hline \multirow[b]{3}{*}{ Age (wk) } & \multicolumn{6}{|c|}{ Paracetamol dose $(\mathrm{mg} / \mathrm{kg})$} \\
\hline & \multicolumn{2}{|c|}{0} & \multicolumn{2}{|c|}{300} & \multicolumn{2}{|c|}{500} \\
\hline & GOT & GPT & GOT & GPT & GOT & GPT \\
\hline 2 & $18 \pm 4$ & $5 \pm 2$ & $20 \pm 3$ & $13 \pm 3$ & $31 \pm 5$ & $13 \pm 4$ \\
\hline 3 & $20 \pm 7$ & $15 \pm 5$ & $29 \pm 4$ & $22 \pm 8$ & $218 \pm 27^{*}$ & $480 \pm 62 *$ \\
\hline $8-10$ & $22 \pm 3$ & $10 \pm 3$ & $39 \pm 6$ & $12 \pm 3$ & $619 \pm 11^{*}$ & $797 \pm 11^{*}$ \\
\hline $24-26$ & $12 \pm 2$ & $17 \pm 3$ & $31 \pm 7$ & $68 \pm 12^{*}$ & $426 \pm 25^{*}$ & $684 \pm 35^{*}$ \\
\hline $32-34$ & $17 \pm 4$ & $21 \pm 5$ & $27 \pm 4$ & $121 \pm 28^{*}$ & $631 \pm 49^{*}$ & $826 \pm 41^{*}$ \\
\hline $52-54$ & $13 \pm 5$ & $13 \pm 6$ & $256 \pm 38^{*}$ & $596 \pm 52 *$ & $845 \pm 63^{*}$ & $883 \pm 34^{*}$ \\
\hline
\end{tabular}

* Significantly different from controls (analysis of variance of logtransformed data with Dunnett's test, $p<0.05$ ).

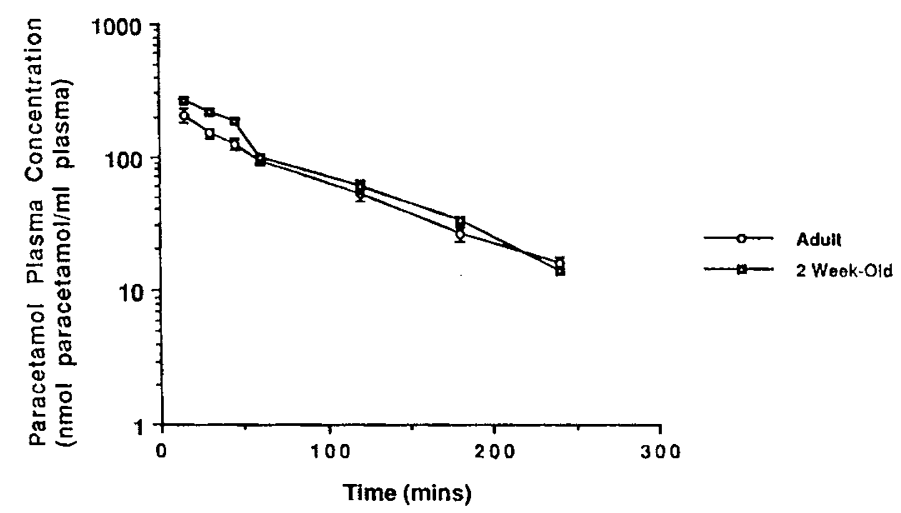

Fig. 1. Paracetamol concentration in plasma after administration of $50 \mathrm{mg} / \mathrm{kg}{ }^{14} \mathrm{C}$-paracetamol to adult (8- to 10 -wk-old) and 2-wk-old mice. Each point represents the mean \pm SEM of samples from four mice.

Table 3. Fractional clearance rates $(\mathrm{mL} / \mathrm{h} / \mathrm{kg})$ of paracetamol and its metabolites into urine in adult (8 to 10-wk-old) and postnatal (2-wk-old) mice (mean $\pm S D$ )

\begin{tabular}{lrc}
\hline & Adult & Postnatal \\
\hline Paracetamol & $153 \pm 11$ & $277 \pm 29^{*}$ \\
Glucuronide & $590 \pm 17$ & $406 \pm 10^{*}$ \\
Sulphate & $98 \pm 22$ & $89 \pm 10$ \\
GSH-derived & $76 \pm 12$ & $138 \pm 38^{*}$ \\
metabolites $\dagger$ & & \\
\hline
\end{tabular}

* Denotes statistically different from adult, $p<0.05$ ( $t$ test).

† Glutathione, cysteine, and mercapturate conjugates.

adult mice $(p<0.05)$. Table 3 documents the fractional clearance rates of paracetamol and its major metabolites into urine. Total recovery of the injected dose $8 \mathrm{~h}$ after paracetamol administration for adult and 2-wk-old mice was $85 \pm 2.7$ and $92 \pm 1.4 \%$, respectively. Of this, 87 and $91 \%$, respectively, could be accounted for as either paracetamol or one of its metabolites eluting from the HPLC column. The fractional clearance rate of the glucuronide conjugate was greater in the adults, whereas that of the sulfate conjugate was similar. The important finding was that the fractional clearance of the GSH-derived metabolites (mercapturate, cysteine, and GSH) of paracetamol was faster in the 2 -wk-old mice $(138 \mathrm{~mL} / \mathrm{h} / \mathrm{kg})$ than in adult mice $(76 \mathrm{~mL} / \mathrm{h} / \mathrm{kg})$. After its formation from paracetamol at low doses, NAPQI reacts with GSH to produce a nontoxic conjugate. This can be further metabolized to either a cysteine or mercapturate conjugate. Therefore, the total of these three conjugates after a nontoxic dose is a measure of the amount of NAPQI formed. Because the fractional clearance of these metabolites is faster in 2-wk-old mice than in adult mice, it indicates that the activation pathway via cytochrome P-450 that produces NAPQI is greater in the 2wk-old mice.

\section{DISCUSSION}

Our study indicates that 2-wk-old mice are remarkably resistant to the hepatotoxic effects of high doses of paracetamol when compared with older age groups. This conclusion is based on three lines of evidence: lethality data, morphologic evidence, and biochemical indices of liver injury.

Of the ages examined in our study, the 1-y-old mice were the most susceptible to the lethal effects of paracetamol. Only at this age did the lower dose of paracetamol $(300 \mathrm{mg} / \mathrm{kg})$ cause lethality, hepatic necrosis, and elevation of both transaminase activities. Also, $90 \%$ of this age group died at the $500-\mathrm{mg} / \mathrm{kg}$ dose. However, although there was some centrilobular derangement in 2-wk-old mice, there was no evidence of liver necrosis after administration of either the $300-$ or $500-\mathrm{mg} / \mathrm{kg}$ dose at this age. Also, there was no elevation of plasma transaminase activities in the 2-wk-old mice, and this was consistent with the lethality and morphologic data indicating marked resistance to toxic effects at this age. Necrosis was evident in the livers of mice aged $3 \mathrm{wk}$ and older that received the higher dose of paracetamol. Although the data are insufficient to indicate a clear age-related change in susceptibility in the adult mice, the remaining adult age groups appeared to be intermediate between the postnatal ages and the 1 -y-old mice, inasmuch as there was no evidence that the lower dose produced marked liver injury. There was also an indication that 3-wk-old mice are intermediate between the 2-wk-old and adult age groups. Lethality was reduced at this age and liver necrosis was less extensive than in adults. These results are consistent with previous studies in mice. Mancini et al. (11) found that the $\mathrm{LD}_{50}$ of paracetamol during the postnatal period was greater than that in adult mice. Similarly, Hart and Timbrell (10) found less necrosis in 3-and 8-d-old mice compared with 35-d-old mice. Beierschmitt et al. (21) found that 3-mo-old mice were more susceptible to paracetamol hepatotoxicity than 1 - and 2-mo-old mice.

A simple explanation for the lack of susceptibility of the 2-wkold mice would be that they lack the enzymes that activate paracetamol to its reactive metabolite. This is certainly not the case. In fact, at $2 \mathrm{wk}$ of age these mice have greater capacity to activate paracetamol to NAPQI than do adults. The fractional clearance rate of the GSH-derived metabolites of paracetamol by this cytochrome P-450-mediated pathway at 2 wk was $80 \%$ greater than that in 8- to 10-wk-old mice. Thus, 2 -wk-old mice have a greater capacity to produce NAPQI, yet are less susceptible to its toxic effects. This result is consistent with our previous findings that hepatocytes from 2-wk-old mice generate NAPQI at a greater rate than those from adults (22).

Inasmuch as the lack of sensitivity to paracetamol toxicity in 2-wk-old mice does not relate to immaturity of the cytochrome P-450 enzyme system, it must be associated with the toxic events initiated by NAPQI formation that ultimately result in irreversible cell damage. It is likely that these toxic processes are quenched by superior defense mechanisms in the postnatal liver cell. It has been shown that the activities of the hepatoprotective enzymes, glutathione peroxidase and glutathione reductase, are markedly higher in the liver of 2-wk-old mice than in adults (23) This may be an important factor because there is evidence supporting a role for oxidative stress in paracetamol toxicity. I1 has been found that inhibition of these enzymes potentiates paracetamol toxicity both in vivo and in vitro $(14,24)$. Therefore the higher level of these hepatoprotective enzymes would protec the liver from oxidative stress induced by paracetamol. A greate capacity to regenerate GSH may also be a factor in this age related difference in susceptibility. Although the basal rate o GSH turnover in 2-wk-old mice is not different from that is adults (23), it has been shown that hepatocytes from postnata 
mice have a greater capacity for GSH resynthesis after depletion of the cytosolic GSH pool with diethylmaleate (25).

The generality of this lack of sensitivity to reactive metabolites during the postnatal period has yet to be fully explored. However, given that postnatal rats have been found to be resistant to paracetamol and bromobenzene $(12,26)$, and mice to paraceta$\mathrm{mol}$ (in our present study), it may be that the postnatal period is characterized by a lack of sensitivity to reactive electrophiles. The relevance of this animal model to changes in paracetamol metabolism during childhood and to the susceptibility of children to the toxic effects of high doses of paracetamol is currently being explored.

\section{REFERENCES}

1. Mitchell JR, Jollow DJ, Potter WZ, Davis DC, Gillette JR, Brodie BB 1973 Acetaminophen-induced hepatic necrosis I. Role of drug metabolism. J Pharmacol Exp Ther 187:185-194

2. Mitchell JR, Jollow DJ, Potter WZ, Gillette JR, Brodie BB 1973 Acetaminophen-induced hepatic necrosis IV. Protective role of glutathione. J Pharmacol Exp Ther 187:211-217

3. Potter WZ, Davis DC, Mitchell JR, Jollow DJ, Gillette JR, Brodie BB 1973 Acetaminophen-induced hepatic necrosis III. Cytochrome P-450 mediated covalent binding in vitro. J Pharmacol Exp Ther 187:203-210

4. Wendel A, Feuerstein S 1981 Drug induced lipid peroxidation in mice I Modulation of monooxygenase activity, glutathione and selenium status. Biochem Pharmacol 30:2513-2420

5. Harman AW 1985 The effectiveness of antioxidants in reducing paracetamolinduced damage subsequent to paracetamol activation. Res Commun Chem Pathol Pharmacol 49:215-228

6. Rumack BH 1985 Acetaminophen: acute overdose toxicity in children. Drug Intell Clin Pharm 19:911-912

7. Rumack BH 1978 Acetaminophen overdose: incidence, diagnosis and management. Pediatrics 62:880-889

8. Alhava E, Hassinen K, Nieminen E 1978 Toxicity of paracetamol in relation to age in mice. Acta Pharmacol Toxicol 42:317-319

9. Goldenthal EI 1971 A compilation of LD50 values in newborn and adult animals. Toxicol Appl Pharmacol 18:185-207
10. Hart JG, Timbrell JA 1979 The effect of age on paracetamol hepatotoxicity in mice. Biochem Pharmacol 28:3015-3017

11. Mancini RE, Sonawane BR, Yaffe SJ 1980 Developmental susceptibility to acetaminophen toxicity. Res Commun Chem Pathol Pharmacol 27:603-606

12. Green MD, Shires TK, Fischer LJ 1984 Hepatotoxicity of acetaminophen in neonatal and young rats I. Age-related changes in susceptibility. Toxicol Appl Pharmacol 74:116-124

13. Adamson GM, Harman AW 1988 Comparison of susceptibility of hepatocytes from postnatal and adult mice to hepatotoxins. Biochem Pharmacol $37: 4183-4190$

14. Adamson GM, Harman AW 1989 The role of glutathione peroxidase/reductase enzymes in protection of hepatocytes from postnatal and adult mice against paracetamol and tert-butylhydroperoxide toxicity. Biochem Pharmacol 38:3323-3330

15. Bergmeyer HU, Bernt E 1974 Glutamate-oxaloacetate tranaminase. In: Bergmeyer HU (ed) Methods of Enzymatic Analysis, Vol 2. Academic Press, New York, pp 727-751

16. Bergmeyer HU, Bernt E 1974 Glutamate-pyruvate transaminase. In: Bergmeyer HU (ed) Methods of Enzymatic Analysis, Vol 2. Academic Press, New York, pp 752-767

17. Culling CFA 1963 Handbook of Histological Techniques, 2nd Ed. Butterworths Co, London

18. Prescott LF 197I The gas-liquid chromatographic estimation of phenacetin and paracetamol in plasma and urine. J Pharm Pharmacol 23:111-115

19. Moldeus P 1978 Paracetamol metabolism and toxicity and in isolated hepatocytes from rat and mouse. Biochem Pharmacol 27: 2859-2863

20. Grimm H 1973 Analysis of variance. In: Delaunois AL (ed) Biostatistics in Pharmacology, Vol 2. Pergamon Press, Oxford, pp 675-716

21. Beierschmitt WP, Brady JT, Bartolone JB, Wyand DS, Khairallah EA, Cohen SD 1989 Selective protein arylation and the age dependency of acetaminophen hepatotoxicity in mice. Toxicol Appl Pharmacol 98:517-529

22. Harman AW, McCamish LE 1986 Age-related toxicity of paracetamol in mouse hepatocytes. Biochem Pharmacol 35:1731-1735

23. Harman AW, McKenna M, Adamson GA 1990 Postnatal development of enzyme activities associated with protection against oxidative stress. Biol Neonate 57:187-193

24. Nakae D, Oakes JW, Farber JL 1988 Potentiation in the intact rat of the hepatotoxicity of acetaminophen by 1,3-bis(2-chloroethyl)-1-nitrosourea. Arch Biochem Biophys 267:651-659

25. Harman AW, Henry CA 1987 Differences in glutathione synthesis and glutathione-S-transferase activities in hepatocytes from postnatal and adult mice. Biochem Pharmacol 36:177-179

26. Green MD, Fischer LJ 1984 Hepatotoxicity of acetaminophen in neonatal and young rats II. Metabolic aspects. Toxicol Appl Pharmacol 74:125-133 